\title{
Correction to: Production of a Recombinant Dermaseptin Peptide in Nicotiana tabacum Hairy Roots with Enhanced Antimicrobial Activity
}

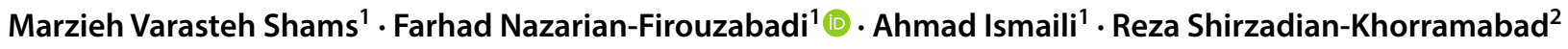

Published online: 12 February 2019

(c) Springer Science+Business Media, LLC, part of Springer Nature 2019

\section{Correction to: Molecular Biotechnology \\ https://doi.org/10.1007/s12033-019-00153-x}

The original version of this article unfortunately contained a mistake in the unit " $\mu \mathrm{g} / \mathrm{l}$ ". The unit " $\mu \mathrm{g} / \mathrm{l}$ " should be corrected to " $\mu \mathrm{g} / \mathrm{ml}$ " throughout the paper.

Publisher's Note Springer Nature remains neutral with regard to jurisdictional claims in published maps and institutional affiliations.

The original article can be found online at https://doi.org/10.1007/ s12033-019-00153-x.

Farhad Nazarian-Firouzabadi

Nazarian.f@lu.ac.ir

Marzieh Varasteh Shams

shams_2424@yahoo.com

Ahmad Ismaili

Ismaili.A@lu.ac.ir

Reza Shirzadian-Khorramabad

r.shirzadian@guilan.ac.ir

1 Agronomy and Plant Breeding Department, Faculty of Agriculture, Lorestan University, Khorramabad, Iran

2 Department of Agricultural Biotechnology, Faculty of Agricultural Sciences, University of Guilan, Rasht 4199613776, Iran 